УДК 929 Біланчин 911/631.4

\title{
ЯРОСЛАВ МИХАЙЛОВИЧ БІЛАНЧИН (НЕКРОЛОГ)
}

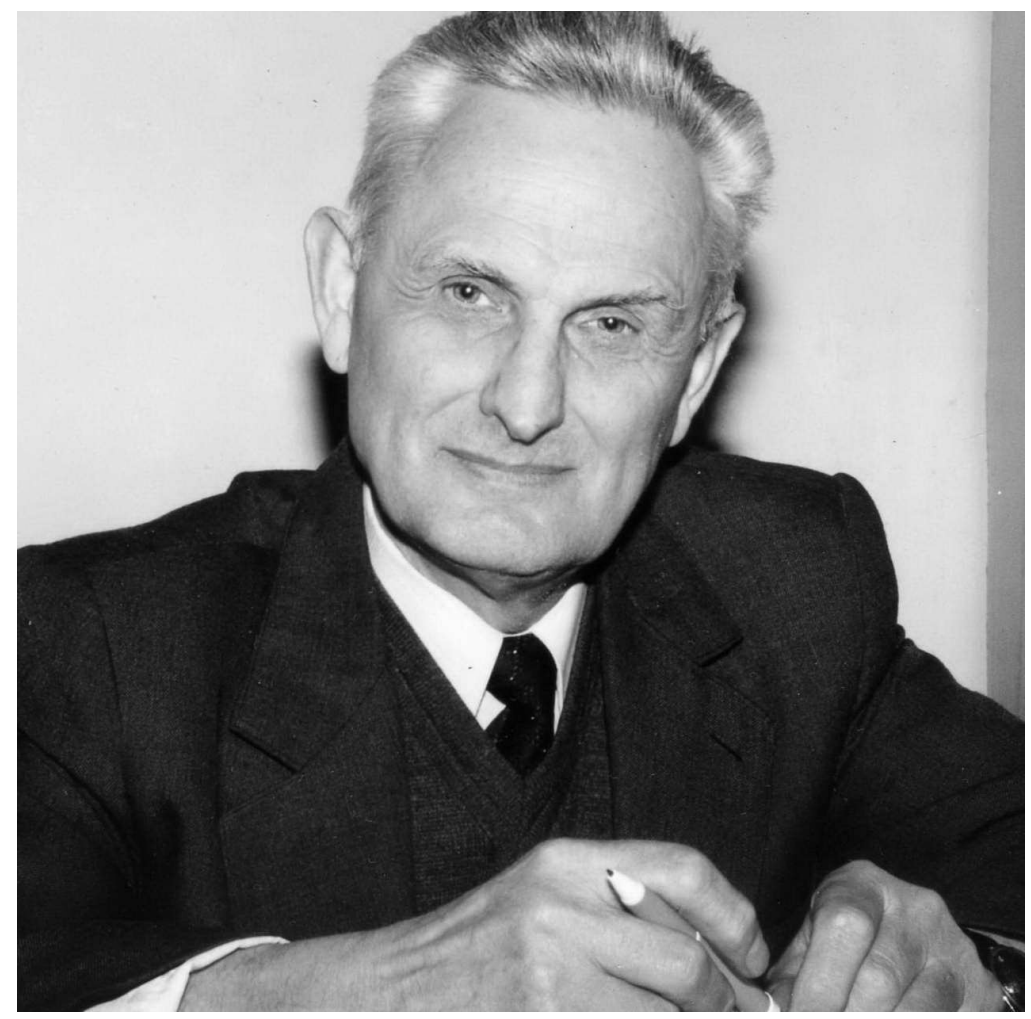

14 березня 2020 р. перестало битися серце Людини з великої літери, географа-грунтознавця, завідувача кафедри географії України, грунтознавства i земельного кадастру Одеського університету імені I.I. Мечникова - Ярослава Михайловича Біланчина. Душа відлетіла до небес, а з тим і закінчилася земна «епоха Біланчина» на геолого-географічному факультеті нашого університету. Безумовно, що ця «епоха» закінчилась фізично, але ментально - його дух, світлий розум та постать завжди залишаться з нами.

Нещодавно відзначали його 80-річчя та проводили за його керівництва у 2019 році конференцію до 100-річчя засновника кафедри грунтознавства і географії грунтів Одеського університету, професора, доктора сільськогосподарських наук Івана Миколайовича Гоголєва, який передав у 1995 році кафедру, створену у далекому 1967 році, своєму учневі, продовживши «життя» наукової школи «гоголєвського грунтознавства». До останніх днів свого життя, Ярослав Михайлович активно працював, ведучи лекційні та лабораторно-практичні за- 
няття, керуючи науковою роботою студентів і співробітників кафедри та Проблемної науково-дослідної лабораторії географії грунтів і охорони грунтового покриву чорноземної зони (ПНДЛ-4) ОНУ. Особливо він переживав за збереження як кафедри, так і ПНДЛ-4 ОНУ. Це для нього була певна місія, збереження пам'яті про Вчителя - проф. Гоголєва I. М.

Народився Ярослав Михайлович в селі Велика Тур'я Долинського району (нині - Івано-Франківська область) 01 січня 1939 року. В 1957 р. після закінчення Самбірського педагогічного училища зі здобуттям кваліфікації вчителя початкової школи, вступив до Львівського університету імені Івана Франка на географічний факультет. Наполегливість, любов до природознавства та надзвичайно велика працездатність вразили I.М. Гоголєва, який запропонував Ярославу Михайловичу прийняти участь у роботах грунтознавчої експедиції. Так, починаючи з 1958 року Ярослав Михайлович зв'язав своє життя з вивченням природи та грунтів. Спочатку це були експедиційні грунтознавчі дослідження на Волині, Львівщині, Закарпатті. Згодом став учасником великомасштабних досліджень і картографування грунтів у грунтознавчій експедиції Львівського університету на посадах інженера, старшого інженера і начальника партії, закінчивши університет у 1962 році і до свого переїзду за Вчителем до Одеси у 1967 році. В цей період з 1962-1967 рр. приймав участь у дослідженні грунтів і картографуванні грунтового покриву колгоспів і радгоспів Радянського Союзу. Географія його робіт - це терени Полтавської області Української РСР, Вологодської, Пермської і Читинської областей і Красноярського краю Російської РФСР, Північно-Казахстанської і Карагандинської областей Казахської РСР. У 1967 р. слідом за своїм Вчителем І. М. Гоголєвим Ярослав Михайлович їде до Одеси, де вступає до аспірантури на новостворену I. М. Гоголєвим кафедру грунтознавства і географії грунтів Одеського університету. 31969 року Ярослав Михайлович переходить на посаду асистента за проханням Івана Миколайовича, залишивши очну аспірантуру та дописуючи кандидатську дисертацію уже в заочній аспірантурі. Згодом перейшов на посаду старшого викладача кафедри та у 1971 році захистив матеріали своїх та кафедральних досліджень природи та грунтів північного Казахстану у кандидатській дисертації «Почвы колочной лесостепи Ишим-Тобольского междуречья в пределах Северо-Казахстанской области».

Починаючи з 1971 році, одночасно зі створенням при ОНУ ПНДЛ-4, Ярослав Михайлович розширює географію та глибину своїх наукових досліджень. Розпочинаються дослідження грунтотворних і ландшафтно-геохімічних процесів у чорноземах в умовах зрошення і дренажу. Географія досліджень - масиви зрошення Українського Придунав'я та Нижнього Дністра на Одещині, Очаківський масив Миколаївщини, Краснознам'янської і Каховської систем Херсонської і Запорізької областей, окремі масиви зрошення північного Криму. Результатами цих робіт користувалися науковці і практики всього бувшого Радянського Союзу та інших країн світу. Численні наукові праці, методичні 
рекомендації щодо збереження і охорони екосистем при зрошенні стали візитівкою та надбанням кафедри та ПНДЛ-4 ОНУ. Результати цих робіт заклали фундамент науковця, його світогляд відносно проблем зрошення чорноземів водами різної якості та дали поштовх і до його кар'єрного зростання на геолого-географічному факультеті університету. 31972 року Ярослав Михайлович на посаді доцента кафедри грунтознавства і географії грунтів. Головне досягнення Ярослава Михайловича в той час як керівника-учителя - захист кандидатської дисертації його учнем П. І. Жанталаєм. Безумовно, що робота науковця кропітка, вимагає надзвичайно великих організаційних та моральних зусиль щодо досягнення результатів, ставить низку вимог передусім до себе, а потім і до інших. Всі ці особливості характеру були притаманні Ярославу Михайловичу від початку становлення науковця і до останнього його подиху.

У 1985 році розпочалася нова «епоха» деканства на геолого-географічному факультеті, адже саме тоді Ярослав Михайлович став його деканом. Беззмінно очолював геолого-географічний факультет до 2007 року. «Епоха деканства Біланчина» тривала 22 роки. За час існування факультету, починаючи 31932 року, це досягнення поки що ніхто не перевершив, i, навряд, чи ще комусь це вдасться в майбутньому. Беззаперечно, що Ярослав Михайлович на відмінно керував факультетом, в його роки правління факультет набув найвищого свого розвитку як у навчальних показниках, так і у наукових. Починаючи з 1991 року, науковцями кафедри та ПНДЛ-4 ОНУ було закладено унікальну систему грунтово-екологічного моніторингу зрошуваних та постзрошуваних земель Придунав'я в межах Одеської області. Активним фундатором тих робіт виступав також Ярослав Михайлович, наукові ідеї якого продовжують в теперішній час його колеги та учні. Починаючи з 1995 року, Ярослав Михайлових очолив рідну кафедру та перейняв від свого Вчителя I. М. Гоголєва наукове керівництво ПНДЛ-4.

Основні наукові досягнення Ярослава Михайловича - це численні методичні вказівки та рекомендації, декілька монографій, сотні наукових публікацій, декілька десятків науково-технічних звітів та професійних виступів на численних конференціях та професійних з'їздах науковців та практиків географії, грунтознавства, сільського господарства тощо; навчальні досягнення - численні навчально-методичні посібники та розробки, фахові на високому рівні лекції, лабораторно-практичні та семінари, та все ж таки головне досягнення його роботи - це його учні - тисячі студентів, які пройшли його «школу».

Окрім традиційних для кафедри і ПНДЛ-4 ОНУ досліджень зрошуваних чорноземів півдня України, Ярослав Михайлович з особливим завзяттям долучився до вивчення природно-географічних умов та грунтів острова Зміїний. Починаючи з 2003 р. під його науковим керівництвом, вперше на острові Зміїний було розпочато вивчення природно-екологічних умов і ресурсів, дослідження грунтів і картографування грунтового покриву. За результатами цих робіт і досліджень були захищені дипломні роботи бакалаврів, спеціалістів та магістрів, 
а також кандидатські дисертації Буяновського А. О. та Леонідової І. В.

Окреме місце у наукових дослідженнях Ярослава Михайловича займали питання вивчення і збереження грунтів і грунтового покриву заповідних територій регіону. Особливе значення мали дослідження природних умов і грунтів Нижньодністровського національного парку, ландшафтно-грунтово-географічних досліджень групи Тузловських лиманів, басейну Куяльницького лиману, згадуваного вище загальнозоологічного заказника острова Зміїний тощо. За результатами цих робіт окрім створених грунтових карт та виданих статей, були захищені магістерські роботи студентів кафедри та кандидатська дисертація Ходос О. С. При всій цій занятості, Ярослав Михайлович завжди знаходив час на вивчення питання розвитку географічних наук в університеті, результатом чого були численні фахові публікації та розділи монографій.

Беззаперечно, що Ярослав Михайлович - талановитий науковець та педагог. На високому рівні викладав кафедральні навчальні дисципліни, вчив і водночас вчився сам. Притаманна йому доброзичливість до студентів та здорова робоча атмосфера під час навчальних занять завжди відзначалась потім випускниками кафедри та факультету. На високому рівні Ярослав Михайлович викладав навчальні дисципліни на усіх освітньо-кваліфікаційних рівнях факультету «Грунтознавство», «Грунти і земельні ресурси світу і України», «Дослідження, картографування та моніторинг грунтів», «Основи меліорації грунтів і земель», «Методика викладання фахових дисциплін в вищій школі», «Фізична географія України», «Грунтово-екологічний моніторинг» та багато ін. Традиційними для навчальної діяльності Ярослава Михайловича були висока вимогливість до якості студентських, аспірантських та наукових досліджень співробітників кафедри та ПНДЛ-4, підготовки наукових робіт та публікацій, їх апробація та захист. Він здійснював керівництво асистентською практикою магістрів, а також керівництво курсовими, кваліфікаційними дипломними (бакалавра, спеціаліста, магістра) та дисертаційними (аспіранти, здобувачі) роботами. За його керівництва студентські роботи неодноразово посідали призові місця на Всеукраїнських олімпіадах з географії та Всеукраїнських конкурсах студентських наукових робіт з географії та екології. Вдало організовував та активно приймав участь у проведенні польових експедиційних досліджень кафедри i ПНДЛ-4. Особливого значення у становленні як особистості для його учнів були сумісні польові дослідження. Надзвичайно важливе значення приділяв проведенню польових навчальних і виробничих практик для студентів кафедри i факультету, зосереджуючи на цьому увагу усіх співробітників кафедри при проведенні практик у студентів факультету, як викладачів-керівників практик, так і навчально-допоміжний персонал кафедри як відповідальних за належне матеріально-технічне забезпечення та організацію техніки безпеки.

За свою сумлінну, бездоганну та високопрофесійну працю нагороджений численними подяками та грамотами, відзнакою НАНУ «За наукові досягнення», нагрудними знаками «За відмінні успіхи в роботі», «Відмінник праці», 
«Відмінник освіти», Почесною відзнакою Одеського міського голови, Почесною грамотою та відзнакою (наручним годинником) Одеської обласної ради та ін.

Висока працездатність, фаховість та професіоналізм, надзвичайно висока відповідальність зумовили його багаторічну працю у різних експертних колах. Він був членом науково-методичної ради з географії Міністерства освіти і науки України, головою навчально-методичної комісії геолого-географічного факультету, членом Вченої ради університету, навчально-методичної ради університету та геолого-географічного факультету, членом редакційної колегії наукового журналу «Вісник Одеського національного університету». Всього і не пригадаєш.

Колектив кафедри, факультету, деканату та адміністрація університету сумують 3 приводу його смерті, та висловлюють співчуття рідним і близьким Ярослава Михайловича. Світла пам'ять про Ярослава Михайловича завжди залишиться в наших думках. 